\section{IJ§ER}

ISSN: 2149-5939
International Journal of Social Sciences and Education Research

Online, http://dergipark.gov.tr/ijsser

Volume: $2(1), 2016$

\title{
A study to examine the health interest level of fast food consumers ${ }^{1}$
}

\author{
Aykut Yilmaz $^{2} \quad$ Yusuf Arslan ${ }^{3}$
}

Received Date: 03 / $10 / 2015$

Accepted Date: $01 / 01 / 2016$

\begin{abstract}
The purpose of the study is to assess the health interest level of fast food consumers and the effecting factors. To reach this aim, four main hypotheses tested in the study. A questionnaire was formed to collect the data needed to test the hypothesis. The questionnaire was carried out to the 211 fast food consumers at main fast food restaurants in Sakarya/Turkey. Both intentional and convenience sampling methods was used in the study, picking voluntary fast food consumers at the restaurants. The results indicate that, health interest of fast food consumers is at medium-high level (3.36 out of 5). Health interest level of fast food consumers increased in direct proportion to the increase of monthly income level. Also, the more a person visits a fast food restaurant the less her/his health interest level become. It also can be seen from the results that marital and child having situation are both significantly related to the heath interest level of fast food consumers. Thus, according to the results, all four hypotheses of the study was supported.
\end{abstract}

Keywords: Fast Food Consumption, Consumer Health Interest, Marketing strategy

\section{Introduction}

Obesity is a serious medical disorder that causes various types of diseases which affects the life time and quality in a negative way unless it is prevented. The prevalence of obesity and its influences on health in Turkey is increasing as well as in other countries all around the world on a daily basis (Republic of Turkey Ministry of Health, 2015a)..

One of the subtitles of the Consumption Expenses research which is being implemented by Turkish Statistical Institute every year is Food Drink Service Expenses. According to the results of this research, which is the indicator of the out-of-home consumption in Turkey, it is visible that there is more than 4 times between $2004-2013$ (Table 1). The raise in the population is approximately $15 \%$ between the same years.

The share of the out-of-home consumption over the total food expenses have grown up to $50 \%$ from 34\% between 1974-2004 in the USA (Stewart, et all, 2006: 1). As it is shown in Table 1, even though the raise of the share of out-of-home consumption over total food expenses has decreased in recent years, we can see that there is still a growth of nearly 2 times of the amount in the last decade.

\footnotetext{
${ }^{1}$ Presented at the ICSER-International Conference on Social Sciences and Education Research, Octo-ber 29-31 October 2015, Turkey, Antalya

${ }^{2}$ Lec., Sakarya University, Vocational School of Sakarya, Program of Accounting and Tax Applications, SAKARYA/TURKEY, aykuty@sakarya.edu.tr

${ }^{3}$ Res. Asst., Sakarya University, Faculty of Management, Production Management and Marketing, SAKARYA/TURKEY, yusufarslan@sakarya.edu.tr
} 
Yilmaz, A., Arslan, Y. (2016). A study to examine the health interest level of fast food consumers. International Journal of Social Sciences and Education Research, 2 (1), 110-115.

According to the results of Ipsos' research, restaurants and fast food stores constitute almost the half of the total out-of-home consumption market share (Ipsos Out-of-Home Consumption Research, 2015).

Table 1. Food and beverages service total food expenditures

\begin{tabular}{|c|c|c|c|c|c|}
\hline \multirow[b]{2}{*}{ Year } & \multicolumn{2}{|c|}{ Food and Beverages Service } & \multicolumn{2}{|c|}{ Total Food } & \multirow[b]{2}{*}{$\begin{array}{c}\text { F\&B / } \\
\text { Total } \\
\text { Food }\end{array}$} \\
\hline & $\begin{array}{c}\text { Amount } \\
\left(\text { Milion/TL }{ }^{*}\right)\end{array}$ & $\begin{array}{c}\text { Change \% } \\
\text { (Base Year } \\
\text { 2004) }\end{array}$ & $\begin{array}{c}\text { Amount } \\
\text { (Million/TL) }\end{array}$ & $\begin{array}{c}\text { Change \% } \\
\text { (Base Year } \\
\text { 2004) }\end{array}$ & \\
\hline '04 & 640,6 & $100 \%$ & $3.781,5$ & $100 \%$ & $17 \%$ \\
\hline '05 & 802,2 & $125 \%$ & $4.468,4$ & $118 \%$ & $18 \%$ \\
\hline '06 & 847,5 & $132 \%$ & $5.054,7$ & $134 \%$ & $17 \%$ \\
\hline '07 & $1.027,3$ & $160 \%$ & $5.221,7$ & $138 \%$ & $20 \%$ \\
\hline ‘08 & $1.217,7$ & $190 \%$ & $6.101,5$ & $161 \%$ & $20 \%$ \\
\hline '09 & $1.517,5$ & $237 \%$ & $6.666,6$ & $176 \%$ & $23 \%$ \\
\hline$' 10$ & $1.763,3$ & $275 \%$ & $7.050,1$ & $186 \%$ & $25 \%$ \\
\hline '11 & $2.195,7$ & $343 \%$ & $7.915,3$ & $209 \%$ & $28 \%$ \\
\hline ' 12 & $2.528,7$ & $395 \%$ & $8.636,0$ & $228 \%$ & $29 \%$ \\
\hline '13 & $2.835,0$ & $443 \%$ & $9.730,7$ & $257 \%$ & $29 \%$ \\
\hline
\end{tabular}

The foods, which can be grouped under fast food category, have various types of options for the customers. Almost none of them are healthy among these types. Fast food is especially not recommended for over middle aged people and people who are suffering from diabetes, due to the reason that these kind of foods contain high level of fat, cholesterol, sodium and salt (Yurtman, 2001: 3). Bowman et al. indicated in their research that fast food is the most important cause of the young generation's increasing obesity problem (2004: 116).

\section{Fast food consumption and health interest}

Fast food is the type of food that being served to the customers as limited menus in a quick, self-service way. This kind of foods are generally prepared before and ready to consume (Lundberg, 1984: 223). Fast food is emphasized in Bender \& Bender's Dictionary of Nutrition and Food Technology as the type of foods which are being served in limited menus by using production line techniques. According to this description, fast food is the type of products which offered by the suppliers who tend to specialize in hamburger, pizza, chicken and sandwich (1999: 157). The products that are being mentioned above are examples of western type of fast foods. Döner, Lahmacun, Kebab can be considered as Turkish equivalents (Akbay et al., 2007: 905). Lower prices, speed, social interaction, entertainment, decoration, food quality, accessibility, variety of products etc. can be counted as some of the reasons why people choose to eat at fast food restaurants (Park, 2004: 88; Bayraktar et al., 1995; Binkley, 2006: 372).

Fast food consuming is one of the fundamental reasons for people becoming obese. According to the World Health Organizations' report in 2012, approximately $7 \%$ of the children under five years old are obese. This ratio was previously around 5\% in 1990s (2014: 41). The necessity of an effective intervention against obesity, which has showed up as a result of unhealthy nourishment, has gained great substantiality. Unless this intervention is performed, it is inevitable for the 
Y1lmaz, A., Arslan, Y. (2016). A study to examine the health interest level of fast food consumers.

International Journal of Social Sciences and Education Research, 2 (1), 110-115.

youth of modern age to have a less healthy and a shorter life span than their parents (Olshansky et al., 2005: 1143).

There are some activities carried out by the Republic of Turkey Ministry of Health to increase awareness such as two public service announcements (psa) "Body Mass Index" and "Harek Et! (Take Action)". In addition to that "lower your meal portion", "10.000 steps every day" themed posters and billboards are being used (Republic of Turkey Ministry of Health, 2015b).

It is known that fast food is a factor that creates risks for adults to gain weight. Besides that there is a correlation that the incensement on the health awareness causes the frequency of fast food consumption to decrease (Monge et al., 2013: 1011). Since the negative effects of fast food products on human health have been proved with scientific researches, "healthy fast food" products have started to be served by companies. In addition to that, sharing the findings of these researches via media is also a reason why companies have developed these specific strategies.

\section{Method}

\subsection{The purpose and hypothesis of the study}

A lot of people prefer fast food products for many reasons. Mainly because short preparation times and easiness to get. But, can one say those people who eat fast food that they do not care about their health at all? Or is it like smoking, people know its harms and just keep doing it? In this context, the purpose of this study is to evaluate the fast food consumer's health interest level and the effecting factors. One main research question and three main hypotheses were tested in the study to reach these purposes which are;

$R Q:$ What is the health interest level of fast-food consumers?

H1: There is a significant relationship between fast food consumer's monthly income and health interest level.

H2: There is a significant relationship between fast food consumer's health interest level and fast food restaurant visiting frequency.

H3: Health interest level of fast food consumer differ depending children having situation.

\subsection{The design of the study}

In the light of the objectives of the study, the survey population was identified as people lives in Sakarya/ Turkey and aged above 18, who have consumed fast food products from any fast food restaurant during previous month.

Both convenience and judgmental sampling methods was employed for the study. It was thought to be the best way to get chance to reach fast food consumers while eating. The questionnaire was consisting of two fundamental parts. First part consists of eight Likert questions which measures consumers health interest level of fast food consumers. Second part of the questionnaire was consisting of demographic questions.

The data to test the hypotheses were obtained from a consumer survey which conducted at Sakarya shopping malls between April-May 2014 period. Trained students directly applied the surveys to the people who were eating at fast food restaurants of the shopping malls. After the elimination of the surveys which has lack of information, there were 211 surveys convenient for further analysis. 
Y1lmaz, A., Arslan, Y. (2016). A study to examine the health interest level of fast food consumers.

International Journal of Social Sciences and Education Research, 2 (1), 110-115.

\section{Findings}

According to the demographic findings of the study, $56 \%$ of the population was male while $\% 44$ was female. $61 \%$ of the population was single. $39 \%$ of the population was married and most of them had children ( $27 \%$ of the total population). More than half of the population was graduated from high school and more than 33\% was higher educated. $\% 60$ of the sample had less than 2000TL monthly income.

Table 2. Demographics

\begin{tabular}{|c|c|c|c|c|c|}
\hline Gender & $\mathrm{n}$ & $\%$ & $\begin{array}{l}\text { Educational Sta- } \\
\text { tus }\end{array}$ & $\mathrm{n}$ & $\%$ \\
\hline Male & 93 & 44 & Primary Ed. & 28 & 13 \\
\hline Female & 118 & 56 & High School & 113 & 54 \\
\hline Total & 211 & 100 & Undergraduate & 63 & 30 \\
\hline & & & Graduate & 7 & 3 \\
\hline Marital Status & $\mathrm{n}$ & $\%$ & Total & 211 & 100 \\
\hline Married & 83 & 39 & & & \\
\hline Single & 128 & 61 & Revenue (TL) & $\mathrm{n}$ & $\%$ \\
\hline Total & 211 & 100 & 1.000 and below & 90 & 43 \\
\hline & & & $1.001-2.00$ & 60 & 28 \\
\hline Children Having & $\mathrm{n}$ & $\%$ & $2.001-3.000$ & 40 & 19 \\
\hline Yes & 78 & 37 & $3.001-4.000$ & 15 & 7 \\
\hline No & 133 & 63 & $\begin{array}{c}4001 \mathrm{TL} \text { and } \\
\text { above }\end{array}$ & 6 & 3 \\
\hline Total & 211 & 100 & Total & 211 & 100 \\
\hline
\end{tabular}

General health interest level of the sample is 3.36. It is between the degrees of 3-4 in the likert scale. It can be said that the population has medium-high level of health interest although they all eat fast food products.

Table 3. Separation of the sample according to health interest levels

\begin{tabular}{lcc}
\hline & Frequency & Percent \\
\hline Low & 27 & 12,8 \\
Modarate & 94 & 44,5 \\
High & 90 & 42,7 \\
\hline TOTAL & 211 & 100,0 \\
\hline
\end{tabular}

According to the results of the Chi-square test, monthly income and health interest levels of fast food consumer is significantly related. Thus, H1 Hypotheses is accepted.

Table 4. Monthly income /health interest level crosstab

\begin{tabular}{|c|c|c|c|c|c|c|c|c|}
\hline \multirow[t]{2}{*}{ Groups } & & \multicolumn{3}{|c|}{ Health Interest Level } & \multirow{2}{*}{ Total } & \multirow{2}{*}{$X^{2}$} & \multirow{2}{*}{ df } & \multirow{2}{*}{$\mathrm{p}$} \\
\hline & & Low & Moderate & High & & & & \\
\hline \multirow{5}{*}{$\begin{array}{l}\text { Fast- } \\
\text { food } \\
\text { Res. Vis- } \\
\text { iting } \\
\text { Freq. }\end{array}$} & $\begin{array}{l}\text { Below } \\
\text { 1000TL* }\end{array}$ & 17 & 45 & 28 & 90 & \multirow{4}{*}{18.006} & \multirow{5}{*}{6} & \multirow{4}{*}{.006} \\
\hline & $\begin{array}{l}1001- \\
2000 \mathrm{TL}\end{array}$ & 2 & 22 & 36 & 60 & & & \\
\hline & $\begin{array}{l}2001- \\
3000 \mathrm{TL}\end{array}$ & 5 & 15 & 20 & 40 & & & \\
\hline & $\begin{array}{l}\text { Above } \\
3000 \mathrm{TL}\end{array}$ & 3 & 12 & 6 & 21 & & & \\
\hline & Total & 27 & 94 & 90 & 211 & & & \\
\hline
\end{tabular}

1 cells $(8,3 \%)$ have expected count less than 5 . 
Yilmaz, A., Arslan, Y. (2016). A study to examine the health interest level of fast food consumers.

International Journal of Social Sciences and Education Research, 2 (1), 110-115.

According to the results of the Chi-square test, fast food restaurant visiting frequency level and health interest level of fast food consumers are significantly related. Thus, H2 Hypotheses is accepted.

Table 5. Fast food restaurant visiting frequency /health interest level crosstab

\begin{tabular}{|c|c|c|c|c|c|c|c|c|}
\hline \multirow[t]{2}{*}{ Groups } & & \multicolumn{3}{|c|}{ Health Interest Level } & \multirow{2}{*}{ Total } & \multirow{2}{*}{$X^{2}$} & \multirow{2}{*}{$\mathrm{df}$} & \multirow{2}{*}{$\mathrm{p}$} \\
\hline & & Low & Moderate & High & & & & \\
\hline \multirow{5}{*}{$\begin{array}{l}\text { Fastfood Res. } \\
\text { Visiting Freq. }\end{array}$} & Everyday & 3 & 7 & 6 & 16 & \multirow{4}{*}{15.995} & \multirow{4}{*}{6} & \multirow{5}{*}{.014} \\
\hline & $\begin{array}{l}\text { Several times } \\
\text { in a week }\end{array}$ & 18 & 45 & 30 & 93 & & & \\
\hline & $\begin{array}{l}\text { Several times } \\
\text { in a month }\end{array}$ & 2 & 30 & 31 & 63 & & & \\
\hline & $\begin{array}{l}\text { More than sev- } \\
\text { eral times in a } \\
\text { month }\end{array}$ & 4 & 12 & 23 & 39 & & & \\
\hline & Total & 27 & 94 & 90 & 211 & & & \\
\hline
\end{tabular}

According to the results of Independent Sample t Test, fast food consumers health interest level is significantly different with regard to marital status $(\mathrm{t}=5,16 ; \mathrm{p}<.05)$. According to results it can be said that married fast food consumer's health interest level is significantly higher than single fast food consumers. Thus, H3 Hypotheses is accepted.

Table 6. Comparison of health interest level with respect to marital status

\begin{tabular}{|c|c|c|c|c|c|c|c|}
\hline \multirow[b]{2}{*}{ Groups } & \multirow[b]{2}{*}{$\mathrm{N}$} & \multirow[b]{2}{*}{ Mean } & \multirow[b]{2}{*}{$\begin{array}{l}\text { Std. } \\
\text { Dev. }\end{array}$} & \multirow[b]{2}{*}{$\begin{array}{l}\text { std. er- } \\
\text { ror }\end{array}$} & \multicolumn{3}{|c|}{$\mathrm{t}$-test } \\
\hline & & & & & $\mathrm{t}$ & $\mathrm{df}$ & $\mathrm{p}$ \\
\hline $\begin{array}{l}\text { Married } \\
\text { Single }\end{array}$ & $\begin{array}{c}83 \\
128\end{array}$ & $\begin{array}{l}3.69 \\
3.15\end{array}$ & $\begin{array}{l}.66 \\
.85\end{array}$ & $\begin{array}{l}.073 \\
.075\end{array}$ & 5.16 & 201.21 & $<0.001$ \\
\hline
\end{tabular}

According to the results of Independent Sample t Test, fast food consumer's health interest level is significantly different regarding children having situation. $(t=3.98 ; p<.05)$. According to results, the health interest of fast food consumers having children is significantly higher than those who do not have children. Thus, H4 Hypotheses is accepted.

Table 7. Comparison of health interest levels with respect to children having situation

\begin{tabular}{|c|c|c|c|c|c|c|c|}
\hline \multirow[b]{2}{*}{ Children } & \multirow[b]{2}{*}{$\mathrm{N}$} & \multirow[b]{2}{*}{ Mean } & \multirow[b]{2}{*}{$\begin{array}{l}\text { Std. } \\
\text { Dev. }\end{array}$} & \multirow[b]{2}{*}{$\begin{array}{l}\text { std. er- } \\
\text { ror }\end{array}$} & \multicolumn{3}{|c|}{ t-test } \\
\hline & & & & & $\mathrm{t}$ & df & $\mathrm{p}$ \\
\hline Yes & 78 & 3.63 & .67 & .079 & 200 & 18748 & $<0001$ \\
\hline No & 133 & 3.20 & .86 & .074 & 5.90 & $18 \% .48$ & $<0.001$ \\
\hline
\end{tabular}

\section{Conclusion}

According to the results of the study, it can be said that fast food consumers see themselves as health interested people although they eat unhealthy food. We think it is because of the attitudinal 
Yilmaz, A., Arslan, Y. (2016). A study to examine the health interest level of fast food consumers. International Journal of Social Sciences and Education Research, 2 (1), 110-115.

tendency to act in a better way while answering questions about themselves. It should be emphasized that people who have children, see fast food products unhealthy. Although they considering fast food unhealthy for themselves but eat anyway, it would not be the same when it comes to their children. That is why it can strongly be suggested to fast food companies to improve their unhealthy image specifically for their child-related products.

\section{References}

Akbay, C., Tiryaki, G. Y., \& Gul, A. (2007). Consumer characteristics influencing fast food consumption in Turkey. Food control, 18(8), 904-913.

Bayraktar, M., Babekoğlu, Y., \& Salman, M. (1995). Tüketicilerin Fast Food Restoran Tercihlerini Etkileyen Faktörler. Ankara Üniversitesi Ziraat Fakültesi, Yayın, (1400).

Bender, D. A. (2006). Benders' dictionary of nutrition and food technology. Woodhead Publishing.

Binkley, J. K. (2006). The effect of demographic, economic, and nutrition factors on the frequency of food away from home. Journal of Consumer Affairs, 40(2), 372-391.

Bowman, S. A., Gortmaker, S. L., Ebbeling, C. B., Pereira, M. A., \& Ludwig, D. S. (2004). Effects of fastfood consumption on energy intake and diet quality among children in a national household survey. Pediatrics, 113(1), 112-118.

İpsos Out-of-Home Consumption Research. http://www.ipsos.com.tr/node/1023 (Access Date: 13.05.2015).

Lundberg, D. E. (1989). The hotel and restaurant business (No. Ed. 5). Van Nostrand Reinhold.

Monge-Rojas, R., Smith-Castro, V., Colón-Ramos, U., Aragón, M. C., \& Herrera-Raven, F. (2013). Psychosocial factors influencing the frequency of fast-food consumption among urban and rural Costa Rican adolescents. Nutrition, 29(7), 1007-1012.

Olshansky, S. J., Passaro, D. J., Hershow, R. C., Layden, J., Carnes, B. A., Brody, J., ... \& Ludwig, D. S. (2005). A potential decline in life expectancy in the United States in the 21st century. New England Journal of Medicine, 352(11), 1138-1145.

Park, C. (2004). Efficient or enjoyable? Consumer values of eating-out and fast food restaurant consumption in Korea. International Journal of Hospitality Management, 23(1), 87-94.

Republic of Turkey Ministry of Health http://beslenme.gov.tr/index.php?lang $=$ tr\&page $=95$ (Access Date: 04.05.2015).

Republic of Turkey Ministry of Health, http://www.saglik.gov.tr/SGGM/belge/1-15742/kampanyahakkinda.html (Access Date: 04.05.2015).

Stewart, H., Blisard, N., \& Jolliffe, D. (2006). Let's eat out: Americans weigh taste, convenience, and nutrition (No. 59411). United States Department of Agriculture, Economic Research Service. http://www.ers.usda.gov/media/860870/ eib19.pdf (Access Date: 08.05.2015)

World Health Organization, World Health Statistics 2014, Geneva, pp.41, 2014.

Yurtman, A., Fast Food Sektör Profil Araştırması. İstanbul Ticaret Odası Yayınları, 2001. 